\title{
Spatial Distribution and Patronage of Ecotourism Attractions in Enugu State, Nigeria
}

\author{
T.E. Amalu ${ }^{1 *}$, O.O. Otop ${ }^{2}$, Ugwu Oko ${ }^{3}$, P.E. Oko-Isu ${ }^{4}$ \\ ${ }^{1,2}$ Department of Geography, University of Calabar \\ ${ }^{3,4}$ Department of Public Administration, Akanu Ibiam Federal Polytechnic Unwana-Afikpo, Ebonyi \\ State, Nigeria \\ *titiagento@gmail.com
}

Keywords: Eco-tourism attractions, Eco-tourists' arrivals, International eco-tourists, domestic ecotourists', Eco-tourism development.

\begin{abstract}
This study focused on examining the spatial characteristics and the patronage pattern of attractions and eco-tourism products in Enugu State. Primary and secondary sources of data collection were used to elicit information for the study. The primary sources involved the use of questionnaire survey, interview sessions guided by participatory rural appraisal technique, telephone survey, direct field observation and the use of Geographic Information System techniques. The secondary sources involved the use of documented information in textbooks, journals and registry of eco-tourism attraction across the study area. Findings from the study indicate that forty-one operational ecotourism attractions exist across the study location with the result of the nearest neighbor analysis of 0.93 revealing that ecotourism attractions were randomly distributed across the study area. The study also observed that a total of 6,360 visitors visited and patronized the attractions between 2013 and 2017 with domestic eco-tourists having 56\% of the entire visits to the attractions while visits by international eco-tourists recorded $44 \%$ of the entire visits. Based on the findings, the study recommended that major stakeholders in the tourism industry (government, non-governmental organizations and host communities) should collaborate and corporate to create an enabling environment for more investment opportunities and organize more ecotourism activities in the area. The study also recommended that managers of ecotourism attractions should employ modern marketing strategies to help create more awareness about the ecotourism attractions and its facilities to the entire world.
\end{abstract}

\section{Introduction}

Ecotourism is a nature based tourism that has been touted as one of the world's largest growing industries and it is the world's smokeless industry as it has the lowest level of risk on the environment $[1,2]$. Development of eco-tourism has gained a lot of prominence in the world with a growing interest from both the developed and developing countries. This have made some developed countries declare eco-tourism as a panacea for socio-economic and environmental challenges such as; unemployment, insecurity, poverty, flooding, erosion, plant and animal extinction [3-5].

Eco-tourism as an activity that has played a pivotal role in ensuring that people have the opportunity to recreate, refresh and re-energize themselves in a bid to improve the quest for healthy living [6]. Eco-tourism being in the frontline in the campaign for sustainable environment has also been perceived as the major element for economic growth as has been proven to diversify the economy of many countries across the world [7-9].

In Nigeria, the numerous natural and eco-tourism attractions scattered across the country have encouraged and prompted more socio-economic activities in the country. This has made ecotourism one of the strong nucleuses of the economy prompting a renewed and increasing interest from government and private investors in investing in the sector [3, 10].

In recent times, visitor attractions (natural sites and cultural events) stand out as a key factor that promotes and encourages more eco-tourists' arrivals in destination areas. More so, packaging 
and marketing of eco-tourism attractions also plays a major role in promoting and ensuring good and quality recreation business in eco-tourism destinations $[2,6,11,12]$.

The development of ecotourism has been recognized as a major source of foreign exchange, increase in family income, cultural pluralism, investments, business opportunities and in most cases, it is seen as a catalyst for international and national integration and relations $[1,3,5]$. Ecotourism has also been upheld as an element of educational advancement and environmental sustainability $[9,12,13]$. It has also been embraced as an agent of peace and unity as it has provided opportunities for people to interact and acquire more experience and exposure of the rapid growth of technology across the world [14, 15].

In recent times, Enugu State with its numerous ecotourism sites and rich cultural products has been observed as a strong base for the steady increase in eco-tourists' visits to the State. These ecotourists' who visit and patronize the various ecotourism attractions have one way or the other created impacts on the economy of local people, increase in family income, rising community revenue and advancement in infrastructural development across the State [16-18].

Although several studies [3, 8, 13, 19] have reported the huge benefits of eco-tourism development in Enugu State, little or no study have been carried out to examine the spatial characteristics of ecotourism attractions and their benefits to host communities across the State. It is in this foregoing that this study seeks to provide answers to the following questions;

1) Are ecotourism attractions randomly or regularly distributed within the study area?

2) Does ecotourism attraction have benefits to host or adjoining communities?

3) Do the people and visitors patronize ecotourism products in the area?

\section{Hypotheses}

Ho: Ecotourism attractions are not randomly or regularly distributed across the study area

$\mathrm{H}_{\mathrm{I}}$ : Ecotourism attractions are randomly or regularly distributed across the study area

$\mathrm{H}_{\mathrm{o}}$ : There is no significant variation in the number of visitors to the various ecotourism attractions in the study area

$\mathrm{H}_{\mathrm{I}}$ : There is a significant variation in the number of visitors to the various ecotourism attractions in the study area

\section{Literature Review}

Ecotourism has been identified as one of the world's largest smokeless industries and it is one of the fastest growing industries today [20-22]. The significance of ecotourism has been well recognized in developed and developing countries. In recent times it has emerged as an economic activity of immense global importance $[1,3,6]$.

Ecotourism has found a niche for itself as an effective instrument for generating employment, earning revenue (for destination areas) and foreign exchange (for the country), enhancing environmental preservation, rejuvenation of the culture and tradition and thereby facilitating overall development. The relevance of ecotourism has reached new heights as it has acquired immense social, cultural and economic significance in modern society. The importance of ecotourism is evident from a recent study conducted by the World Tourism Organization (WTO). According to the study, global spending on ecotourism was increasing by $20 \%$ annually since 2010 and this is about six times the average rate of growth for the tourism industry as a whole [23].

The development of visitors' attractions stand out as the strongest pull-factors of a destination and are considered as key destination resources for development and marketing of ecotourism. They are often defined as flagship and iconic objects, which draw a relatively large number of visitors to their premises and region. Although they are often considered a catalyst for economic development $[24,25]$, ecotourism has been praised as a "passport" to development $[3,5,7]$. It has also been hailed as one of the largest and fastest growing sectors of the global political economy. In the same 
vein, ecotourism has been identified as one of the leading sources of foreign exchange and employment opportunities in many countries both in the developed and developing world [11, 15, 17].

It is a general phenomenon that the availability of ecotourism products and services combined with abundant ecotourism attractions stimulate ecotourism development in destination regions [2527]. Nigeria with abundant ecotourism attractions strives to make it the leading eco-tourism base in Africa. The attractions are numerous ranging from places of natural beauty to cultural and historical heritage [20]. Other Nigerian ecotourism components include transportation, accommodation, recreational and entertainment facilities among others [19,21]. All these components combined together make ecotourism a science and art of recreation to the visitors in order to cater for their various needs $[28,29]$. Apart from that, the all-year-round favourable weather in Nigeria makes her a major attraction for eco-tourists across the world. Nigeria is blessed with variety of ecotourism attractions scattered across the country and these attractions are directly associated with comfort as they offer visitors the privilege to take a break away from the difficulties and stress of day to day activities as it provides the context for relaxation and opportunity to do something different and less stressful [30-32].

[15] examined the influence of resorts and recreation centres on socio-economic growth of Calabar, Cross River State, Nigeria. They realized that information from friends and family members is the most frequently used medium of awareness of tourism outfits with a response rate of $36 \%$ followed by the use of sign posts and then social media with $21 \%$ and $18 \%$ respectively. The study also revealed that $89 \%$ of the entire employed workers in tourism based outfits were indigenes of the host community. It was also realized that the tourism industry contributed positively to the host community in various ways as it provided more employment opportunities, increased individual and family income and advanced infrastructural development.

[33] suggested that the location of resorts are based on factors such as the price of land space, state of infrastructures, accessibility of the area, availability or state of basic, social amenities and availability of tourism support facilities. The study also emphasized that these highlighted factors are also determinant factors to the visitor's duration of stay in the area as they determine the level of satisfaction of visitors to the various tourists' attractions.

[34] observed that tourists resorts and attractions are major source of economic advancement of destination areas. They also observed that as a major driving force of economic development, tourism industry has a lot of positive impact on the development of destination regions. These impacts ranges from increment in the number of employed residents by $40 \%$ within the last one year, increased the income of individuals, families and government, improvement in the infrastructures and social amenities to the improvement in esthetics of destination areas. The study also reported that development of ecotourism attractions are carried out with outmost interest based on the anticipated accruing benefits from the development of the tourism industry. It was also observed that the distribution of tourists resorts and attractions within the area were at random as the attractions were mostly natural attractions with calculated nearest neighbor index of 1.02 and the attractions were successfully developed and packaged for visitor's utilization with the aid of optimum interest, proper planning and collaboration of all stakeholders in the industry.

[35] retort that there exists a variation in the level of patronage of various tourists' attractions and that this patronage depends on the number and uniqueness of the facilities of the attractions. The study further examined the challenges of the tourism industry in the area where it realized that lack of interest and collaboration of the stakeholders of the industry as the major challenge to the industry. It also observed other factors such as; lack of tourism support facilities and lack of strategic marketing techniques in the dissemination of information and creation of awareness as regards the facilities of the tourism industry.

\section{Study Area}

Enugu State is located in the Eastern part of Nigeria. It lies between latitudes $6^{\circ} 20^{\mathrm{I}}$ and $6^{\circ} 30^{\mathrm{I}}$ $\mathrm{N}$ and longitudes $7^{\circ} 25^{\mathrm{I}}$ and $7^{\mathrm{O}} 30^{\mathrm{I}} \mathrm{E}$ of the equator [36]. The State shares borders with Abia State 
and Imo State to the South, Ebonyi State to the East, Benue State to the North-East, Kogi State to the North-West and Anambra State to the West. It has a total area of 7,161km $(2,765 \mathrm{sq} . \mathrm{mi})$ and a density of $780 / \mathrm{km}^{2}$ (2,000 sq.mi). Four Local Government Areas across the three senatorial districts of the State were adopted for the study namely; Ezeagu and Udi in the West, Nsukka in the North and Enugu East in the East (Fig. 1)

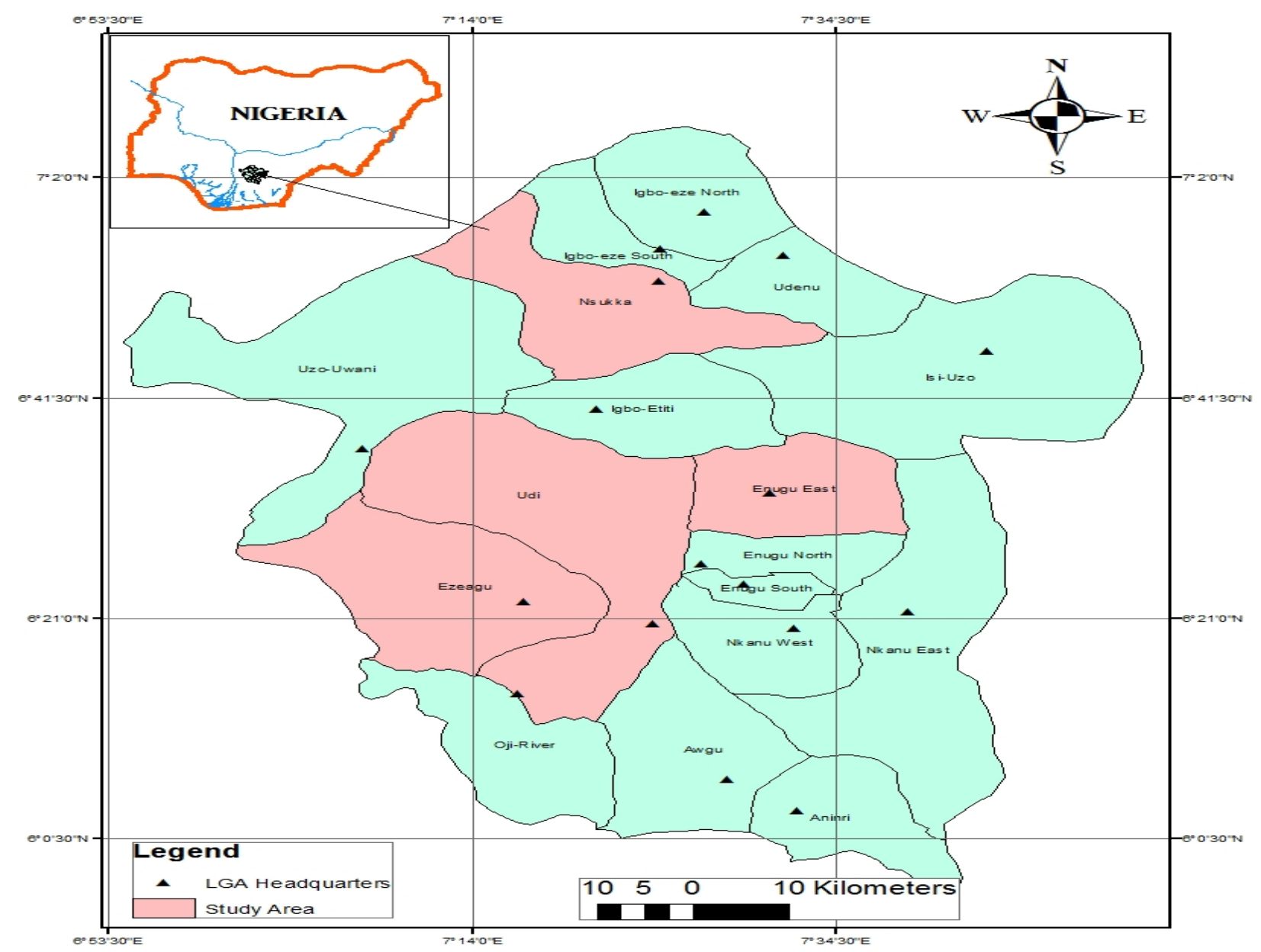

Figure 1. Map of Enugu state showing the study area.

Source: GIS Department of the Cross River State Ministry of Lands and Survey (2018)

\section{Methodology}

Primary and secondary sources of data collection were employed for the study to achieve the aim and objectives of the study. The primary source involved the use of questionnaire, interview sessions, telephone survey, direct field observation and the use of the GIS technique to determine the distances and distribution pattern of the various ecotourism attractions within the study area. The secondary source involved the use of documented information in textbooks, internet materials and registry of ecotourism outfits. The study elicited information from managers and registry of ecotourism outfits and facilities within the area where information such as; visitors visitation and patronage, staff strength and medium of awareness were derived.

The questionnaire survey involved 30 respondents (randomly selected managers of the existing 41 ecotourism attractions within the study area).

The telephone survey involved one hundred and thirteen (113) people (visitors) who had visited the ecotourism attractions between 2013 and 2017. The selection process of the telephone survey respondents was guided by random sampling technique as detail of their telephone contacts were extracted from the registration forms in the registry of the various ecotourism attractions. 
The study also conducted interview sessions with focus persons and owners of ecotourism support facilities within the study area.

Meanwhile, participatory rural appraisal (PRA) method was employed to guide the interview sessions with the aid of a semi- structured check-list.

Data for the study were presented with the aid of tables and charts. The data were analyzed with descriptive statistical techniques such as; mean and simple percentages; the hypothesis were tested with the use of inferential statistical techniques such as nearest neighbor technique and analysis of variance (ANOVA).

\section{Results and Discussion}

\section{Spatial distribution of eco-tourism attractions in the area}

The spatial characteristics of ecotourism attractions were considered in order to examine the pattern of their distribution in the area. Table 1 show that a total of 41 ecotourism attractions were captured for the study across the seven local government areas of the State including 11 lakes, 6 shrines representing, 5 hills, 14 caves and 5 waterfalls across the study locations. These data implies that Enugu State is endowed with very unique ecotourism attractions that posses various functional characteristics of appealing value to the host communities and visitors. The attraction could be touted to be valued as historical, economical, cultural, spiritual, religious, traditional and sometimes aesthetical. Data on Table 2 shows the spatial relationship of various ecotourism attractions and the distribution pattern in terms of measuring the distances of the nearest neighbor to each attraction while Fig. 2 shows a spread of the attractions in the area.

Table 1. Major eco-tourism attractions across the study locations.

\begin{tabular}{|c|c|c|c|c|c|c|}
\hline Area & Lake & Shrine & Hill & Cave & Beach & Waterfall \\
\hline \multirow[t]{7}{*}{ Ezeagu } & Ezeagu tourist complex & & & Ogba-Agana cave & & $\begin{array}{l}\text { Ogba-Agada } \\
\text { waterfall }\end{array}$ \\
\hline & Iheneke lake & & & $\begin{array}{l}\text { Ezeagu } \\
\text { complex }\end{array}$ & & $\begin{array}{ll}\begin{array}{l}\text { Ezeagu } \\
\text { complex }\end{array} & \text { tourist } \\
\end{array}$ \\
\hline & Obinofia Ndiuno lake & & & Ihu-ogba & & Iheneke waterfall \\
\hline & & & & Obinofia cave & & \\
\hline & & & & Odor-Ugwu cave & & \\
\hline & & & & Ogba Umuogubi & & \\
\hline & & & & $\begin{array}{l}\text { Ogba Gwoo Gwoo } \\
\text { cave }\end{array}$ & & \\
\hline Enugu East & Nike lake & Eucalptus reserve & & & & \\
\hline \multirow[t]{2}{*}{ Nsukka } & Opi lake complex & & Nsukka hill & & & \\
\hline & Amagunze/Akpawfu lake & & & & & \\
\hline \multirow[t]{5}{*}{ Udi } & Ogelube lake & Ugwu Owere & $\begin{array}{l}\text { Ugwueme/Udi } \\
\text { hill }\end{array}$ & Awhum cave & & Awhum waterfall \\
\hline & & Eka Ana & Milken hill & Ngwo cave & & Ngwo waterfall \\
\hline & & Isi Ujulu & Silicon hill & Inyi chine & & \\
\hline & & Ugwu Enechhi & & & & \\
\hline & & Wonderful stone & & & & \\
\hline \multirow[t]{3}{*}{ Nkanu } & Ani-Ozalla lake & & & Ogba Ihenekweagu & $\begin{array}{l}\text { Akwuke-Atakwu } \\
\text { beach }\end{array}$ & \\
\hline & Ngebe lake & & & Akpugo cave & Nyaba beach & \\
\hline & Obanukwu lake & & & & & \\
\hline Awgu & & & Awgu hill & Isu Awaa cave & & \\
\hline Oji River & Odoro lake & & & Odoro cave & & \\
\hline
\end{tabular}

Source: Field survey, 2017 
Table 2. Nearest neighbour distances of ecotourism attraction sites in the study area.

\begin{tabular}{|c|c|c|c|c|c|c|}
\hline \multirow[t]{2}{*}{$\mathbf{S} / \mathbf{N}$} & \multirow[t]{2}{*}{ LGA } & \multirow[t]{2}{*}{ Attraction sites } & \multicolumn{2}{|c|}{ GPS } & \multirow{2}{*}{$\begin{array}{c}\text { Average nearest Distance } \\
(\mathbf{k m})\end{array}$} & \multirow[t]{2}{*}{ Nearest attraction } \\
\hline & & & $\begin{array}{l}\text { Latitudes } \\
(\mathbf{N})\end{array}$ & $\begin{array}{l}\text { Longitudes } \\
\text { (E) }\end{array}$ & & \\
\hline 1 & Ezeagu & $\begin{array}{ll}\text { Ezeagu } & \text { tourist } \\
\text { complex } & \\
\end{array}$ & $6^{\circ} 23^{1} 0.2^{I I}$ & $7^{\circ} 27^{1} 59.0^{I I}$ & 0.5 & Iheneke lake \\
\hline 2 & & Iheneke lake & $6^{\circ} 23^{1} 2.4^{11}$ & $7^{\circ} 27^{1} 26.5^{\mathrm{II}}$ & 0.1 & Iheneke waterfall \\
\hline 3 & & Obinofia Ndiuno lake & $6^{\circ} 23^{1} 5.4^{\mathrm{II}}$ & $7^{\circ} 27^{\mathrm{I}} 10.9^{\mathrm{II}}$ & 0.1 & Obinofia cave \\
\hline 4 & & Ogba-Agana cave & $6^{\circ} 23^{1} 6.6^{I I}$ & $7^{\circ} 27^{1} 55.7^{\mathrm{II}}$ & 0.3 & Ogba-Umuogubi cave \\
\hline 5 & & Ihu-ogba cave & $6^{\circ} 23^{\mathrm{I}} 12.0^{\mathrm{II}}$ & $7^{\circ} 27^{\mathrm{I}} 38.3^{\mathrm{II}}$ & 0.5 & $\begin{array}{lll}\text { Ogba } & \text { Gwoo } & \text { Gwoo } \\
\text { cave } & & \end{array}$ \\
\hline 6 & & Obinofia cave & $6^{\circ} 23^{\mathrm{I}} 10.3^{\mathrm{II}}$ & $7^{\circ} 27^{\mathrm{I}} 19.4^{\mathrm{II}}$ & 0.4 & Ogba-Agada waterfall \\
\hline 7 & & Odor-Ugwu cave & $6^{\circ} 23^{\mathrm{I}} 16.9^{\mathrm{II}}$ & $7^{\circ} 27^{\mathrm{I}} 43.3^{\mathrm{II}}$ & 0.8 & Ihu-Ogba cave \\
\hline 8 & & Ogba Umuogubi cave & $6^{\circ} 23^{1} 21.7^{I I}$ & $7^{\circ} 27^{1} 9.1^{11}$ & 1.2 & $\begin{array}{ll}\text { Ezeagu } & \text { tourists' } \\
\text { complex } & \end{array}$ \\
\hline 9 & & $\begin{array}{l}\text { Ogba Gwoo Gwoo } \\
\text { cave }\end{array}$ & $6^{\circ} 23^{1} 26.6^{I I}$ & $7^{\circ} 27^{1} 14.0^{I I}$ & 1.3 & Iheneke lake \\
\hline 10 & & $\begin{array}{l}\text { Ogba-Agada } \\
\text { waterfall }\end{array}$ & $6^{\circ} 23^{1} 56.6^{I I}$ & $7027^{1} 26.6^{I I}$ & 0.4 & Obinofia lake \\
\hline 11 & & Iheneke waterfall & $6^{\circ} 23^{\mathrm{I}} 59.5^{\mathrm{II}}$ & $7^{\circ} 27^{1} 10.9^{I I}$ & 0.5 & $\begin{array}{l}\text { Ezeagu tourists' } \\
\text { complex }\end{array}$ \\
\hline 12 & $\begin{array}{l}\text { Enugu } \\
\text { East }\end{array}$ & Nike lake & $6^{\circ} 24^{1} 44.1^{I I}$ & $7^{\circ} 28^{\mathrm{I}} 51.2^{\mathrm{II}}$ & 1.1 & Eucalptus shrine \\
\hline 13 & & Eucalptus reserve & $6^{\circ} 24^{1} 44.3^{11}$ & $7^{\circ} 28^{1} 31.6^{I I}$ & 1.1 & Nike lake \\
\hline 14 & Nsukka & Opi lake complex & $6^{\circ} 22^{1} 05.8^{I I}$ & $7^{\circ} 29^{1} 33.4^{I I}$ & 1.2 & Akpawfu lake \\
\hline 15 & & Akpawfu lake & $6^{\circ} 22^{\mathrm{I}} 15.3^{\mathrm{II}}$ & $7^{\circ} 29^{1} 48.9^{I I}$ & 1.2 & Opi lake \\
\hline 16 & & Nsukka hill & $6^{\circ} 22^{1} 20.3^{\mathrm{II}}$ & $7^{\circ} 29^{\mathrm{I}} 50.9^{\mathrm{II}}$ & 2.2 & Akpawfu lake \\
\hline 17 & Udi & Ogelube lake & $6^{\circ} 22^{1} 23.0^{\mathrm{II}}$ & $7^{\circ} 29^{\mathrm{I}} 62.8^{\mathrm{II}}$ & 1.7 & Wonder stone \\
\hline 18 & & Ugwu Owere & $6^{\circ} 22^{1} 28.3^{11}$ & $7^{\circ} 29^{\mathrm{I}} 69.8^{\mathrm{II}}$ & 1.2 & Awhum cave \\
\hline 19 & & Eka Ana & $6^{\circ} 22^{\mathrm{I}} 42.4^{\mathrm{II}}$ & $7^{\circ} 29^{\mathrm{I}} 76.3^{\mathrm{II}}$ & 1.6 & Ngwo cave \\
\hline 20 & & Isi Ujulu & $6^{\circ} 22^{1} 52.3^{I I}$ & $7^{\circ} 29^{\mathrm{I}} 82.6^{\mathrm{II}}$ & 0.7 & Ugwu Enechhi \\
\hline 21 & & Ugwu Enechhi & $6^{\circ} 22^{1} 62.9^{I I}$ & $7^{\circ} 29^{\mathrm{I}} 96.3^{\mathrm{II}}$ & 1.5 & Wonderful stone \\
\hline 22 & & Wonderful stone & $6^{\circ} 22^{1} 28.6^{I I}$ & $7^{\circ} 29^{\mathrm{I}} 98.1^{\mathrm{II}}$ & 2.2 & Inyi chine \\
\hline 23 & & Ugwueme/Udi hill & $6^{\circ} 22^{\mathrm{I}} 53.5^{\mathrm{II}}$ & $7^{\circ} 29^{\mathrm{I}} 06.7^{\mathrm{II}}$ & 0.5 & Milken hill \\
\hline 24 & & Milken hill & $6^{\circ} 22^{1} 31.5^{\mathrm{II}}$ & $7^{\circ} 29^{\mathrm{I}} 18.9^{\mathrm{II}}$ & 0.5 & Udi hill \\
\hline 25 & & Silicon hill & $6^{\circ} 22^{1} 22.1^{I I}$ & $7^{\circ} 29^{\mathrm{I}} 20.8^{\mathrm{II}}$ & 1.6 & Eka Ana \\
\hline 26 & & Awhum cave & $6^{\circ} 22^{\mathrm{I}} 14.1^{\mathrm{II}}$ & $7^{\circ} 29^{1} 28.5^{\mathrm{II}}$ & 0.1 & Awhum lake \\
\hline 27 & & Ngwo cave & $6^{\circ} 22^{1} 24.6^{I I}$ & $7^{\circ} 29^{\mathrm{I}} 30.5^{\mathrm{II}}$ & 0.4 & Milken hill \\
\hline 28 & & Inyi chine & $6^{\circ} 12^{1} 16.6^{I I}$ & $7^{\circ} 29^{1} 39.8^{I I}$ & 2.2 & Wonderful stone \\
\hline 29 & & Awhum waterfall & $6^{\circ} 22^{1} 31.5^{\mathrm{II}}$ & $7^{\circ} 29^{\mathrm{I}} 42.9^{\mathrm{II}}$ & 0.1 & Awhum cave \\
\hline 30 & & Ngwo waterfall & $6^{\circ} 22^{1} 46.8^{I I}$ & $7^{\circ} 29^{\mathrm{I}} 45.7^{\mathrm{II}}$ & 0.1 & Ngwo cave \\
\hline 31 & Nkanu & Ani-Ozalla lake & $6^{\circ} 21^{1} 37.9^{I I}$ & $7^{\circ} 26^{1} 10.4^{\mathrm{II}}$ & 5.6 & Obanukwu lake \\
\hline 32 & & Ngebe lake & $6^{\circ} 16^{1} 34.7^{\mathrm{II}}$ & $7^{\circ} 28^{1} 39.2^{11}$ & 6.2 & Akpugo cave \\
\hline 33 & & Obanukwu lake & $6^{\mathrm{o}} 17^{\mathrm{I}} 0.4^{\mathrm{II}}$ & $7^{\circ} 32^{1} 20.5^{\mathrm{II}}$ & 15.4 & Ogba Ihenekweagu \\
\hline 34 & & Ogba Ihenekweagu & $6^{\circ} 21^{\mathrm{I}} 7.1^{\mathrm{II}}$ & $7^{\circ} 33^{1} 52.9^{I I}$ & 12.7 & Nyaba beach \\
\hline 35 & & Akpugo cave & $6^{\circ} 18^{\mathrm{I}} 7.2^{\mathrm{II}}$ & $7^{\circ} 35^{\mathrm{I}} 10.1^{\mathrm{II}}$ & 4.2 & Akwuke beach \\
\hline 36 & & $\begin{array}{l}\text { Akwuke-Atakwu } \\
\text { beach }\end{array}$ & $6^{\circ} 14^{\mathrm{I}} 51.9^{\mathrm{II}}$ & $7^{0} 29^{\mathrm{I}} 25.7^{\mathrm{II}}$ & 11.4 & Nyaba beach \\
\hline 37 & & Nyaba beach & $6^{\circ} 16^{\mathrm{I}} 24.4^{\mathrm{II}}$ & $7^{\circ} 36^{1} 37.4^{I I}$ & 11.4 & Akwuke beach \\
\hline 38 & Awgu & Awgu hill & $6^{\circ} 09^{1} 12.7^{I I}$ & $7^{\circ} 23^{1} 31.1^{\mathrm{II}}$ & 14.6 & Isu Awaa cave \\
\hline 39 & & Isu Awaa cave & $6^{\circ} 04^{\mathrm{I}} 55.7^{\mathrm{II}}$ & $7^{\circ} 24^{1} 1.9^{11}$ & 14.6 & Awgu hill \\
\hline 40 & Orji River & Odoro lake & $6^{\circ} 13^{1} 34.8^{I I}$ & $7^{\circ} 15^{\mathrm{I}} 28.0^{\mathrm{II}}$ & 1.2 & Odoro cave \\
\hline 41 & & Odoro cave & $6^{\circ} 06^{1} 54.0^{\mathrm{II}}$ & $7^{\circ} 16^{1} 29.6^{I I}$ & 1.2 & Odoro lake \\
\hline
\end{tabular}

Source: Field GPS reading, 2017 


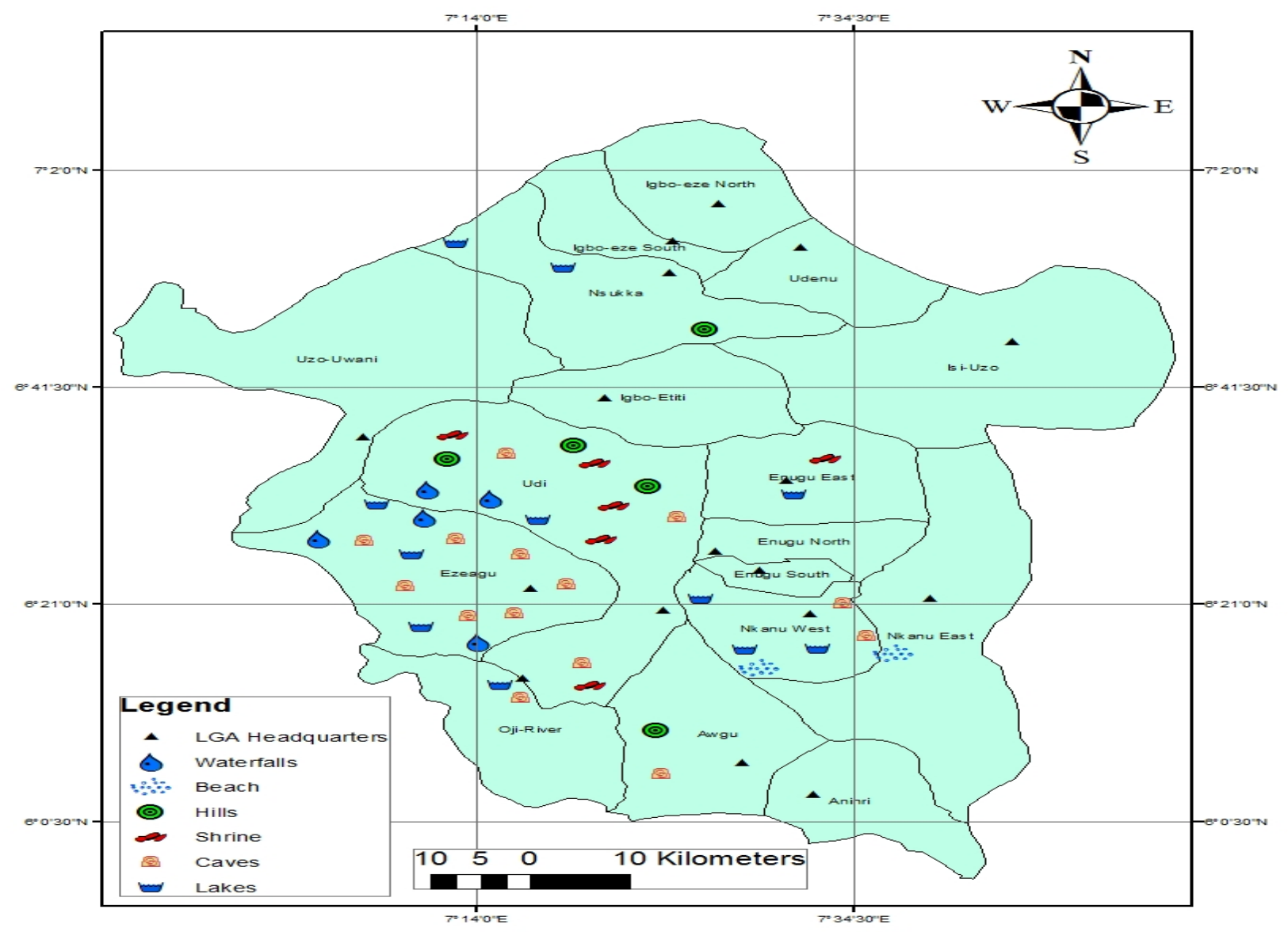

Figure 2. Map showing the spread of eco-tourism sites across Enugu State. Source: Adopted from Nigeria data map (2017)

\section{Challenges limiting visitors' patronage of ecotourism attractions}

In a bid to investigate if there is a variation in the choice of ecotourism attraction in the area, the study examined the pattern of visitors' patronage of the ecotourism attractions in the area. A telephone survey was carried out as shown on Table 3 . Summary of the telephone survey on Table 3 revealed that $55 \%, 50 \%$ and $48 \%$ of visitors' were of the opinion that there were communication facilities, arts gallery and security presence within the various ecotourism attractions. These were noted to be the major pull-factor that attracted the visitors' to the attractions. Further investigation indicates that the decision was prompted due to the sign posts and telecommunication network, sales of local craft work and presence of security personnel around and within some of the sites. Meanwhile, $5 \%$ and $9 \%$ of the tourists expressed that the attraction site lacked financial facilities, food and beverage centres and supermarket respectively, to provide for the needs and satisfaction of the tourists. Information on Fig. 3, presents result of interview session with visitors on the challenges limiting visitors choice of attraction sites in the study area. It further illustrates that $18 \%$ of the entire interviewed tourists pointed out that lack of access roads and accommodation facilities were the main constraints to visitors to the ecotourism sites. Moreover, it was also observed that language barrier, poor marketing technique, and lack to super markets recorded the least frequency of tourists with $5 \%$ of the tourists agreeing that they were the reasons why tourists did not visits the ecotourism sites. This indicates that there were factors responsible for the irregular patronage pattern observed in ecotourism attractions across the study locations. Worthy of note is that the visitors were allowed to make multiple responses of their choice to each item under investigation. 
Table 3. Facilities of the ecotourism attractions in the study area.

\begin{tabular}{|l|c|c|}
\hline \multicolumn{1}{|c|}{ Item } & Number of visitors in acceptance & Percentile difference of responses (\%) \\
\hline Accommodation & 48 & 42 \\
\hline Sports facility & 43 & 38 \\
\hline Arts gallery & 56 & 50 \\
\hline Super market & 10 & 9 \\
\hline Tour guides & 14 & 12 \\
\hline Financial facilities & 6 & 5 \\
\hline Food and Beverage centres & 10 & 55 \\
\hline Communication facilities & 62 & 10 \\
\hline Access roads to the site & 13 & 48 \\
\hline Security personnel & 54 & 21 \\
\hline Electricity facilities & 24 & 100 \\
\hline Total & 340 & \\
\hline
\end{tabular}

Source: Telephone survey, 2017

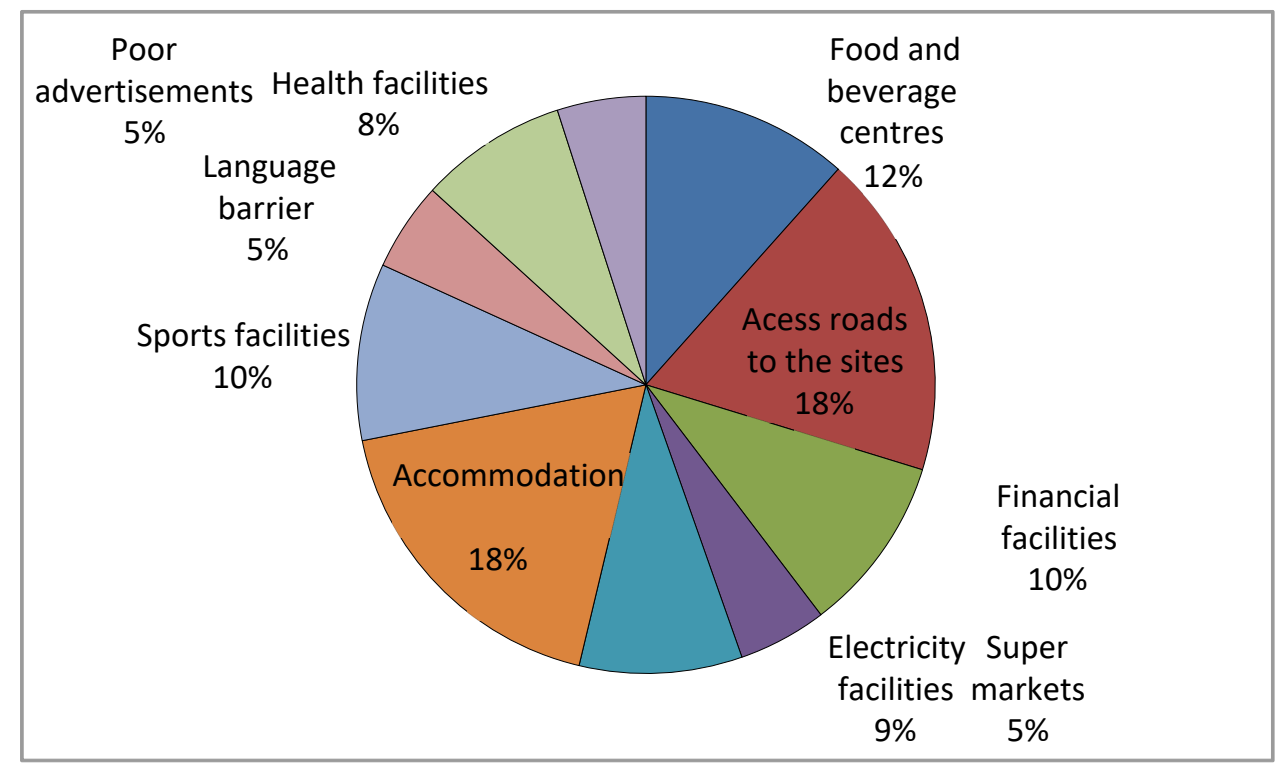

Figure 3. Factors challenging visitors' choice of ecotourism attractions in the study area. Source: Telephone survey, 2017

The study considered the distribution pattern of available eco-tourism sites within the study location and formulated hypothesis for testing using data on Table 2.

$\mathrm{H}_{\mathrm{o}}$ : Ecotourism attractions are not randomly or regularly distributed across the study area of Enugu State

$\mathrm{H}_{\mathrm{I}}$ : Ecotourism attractions are randomly or regularly distributed across the study area in Enugu State

The nearest neighbor analysis was the statistical method adopted in the testing of this hypothesis. Nearest neighbor as a statistical technique attempts to measure the distributions according to whether they are clustered, random or regular. This statistical tool is used to measure the distant between every point and its nearest neighbor and substitute these figures in a formula which will give one figure to describe the distributional pattern under consideration.

As a general rule, Rn values lies between 0 and 2.15, where:

Clustered distribution occurs when the Rn value $\quad=0$

Random distribution occurs when Rn value $\quad=1.0$

Regular distribution occurs when Rn value $\quad=2.15$ 
The formula is given as:

$$
\begin{aligned}
& R n=2 d \sqrt{\frac{n}{A}} \\
& =2 \times 6.17 \sqrt{\frac{41}{7161}}
\end{aligned}
$$

$=12.3 \times 0.076$

$\mathrm{Rn}=0.93$

Decision: From the analysis above, a nearest neighbor analysis (Rn) value of 0.93 was obtained. This shows that ecotourism attractions in Enugu State are randomly distribution across the study area (Fig. 2). This means that the alternate hypothesis is accepted and the null hypothesis rejected. That means that; ecotourism attractions are randomly distributed across the study area.

\section{Patronage of ecotourism attractions}

Patronage of the ecotourism attractions within the State is an important aspect of the study considering the intention of providing the necessary factors that influenced decision of stakeholders to develop the attractions. Information on the number of visits to ecotourism attractions were obtained from the forty one ecotourism attractions within the study area. Table 4 shows that from a total of 2780 visitors to the attractions, 27 percent came from African countries, 19 percent from Asian countries, 17 percent from South American countries and the least number of international visitors were from North America recording 15 percent of the entire visits by international tourists. In addition, Table 5 also revealed that a total of 3580 visitors came from within Nigeria and among this number includes, 10 percent of the visitors were from Cross River and River State respectively while the least number of visitors were recorded by visitors from Kogi State with 4 percent of the entire the visits by domestic visitors.

Information on Table 6 shows the number of visits to the various types of ecotourism attractions within the study area. More so, Table 6 further shows that the ecotourism attractions were classified into five different types namely; lakes, waterfalls, shrines, landscapes and caves. Among the visitors to the various ecotourism attractions, it was observed that the highest number of visits were recorded among those who visited the waterfalls with 35 percent of the entire visitors, 26 percent of the visitors visited the lakes while the shrine recorded the least number of visits with 9 percent of the entire visitors. The interview sessions of the study revealed that visitor's intention to visit an attraction were dependent on level of awareness of the attraction, accessibility to the attraction and support facilities present in the ecotourism sites.

Table 4. International visitors' that visited the ecotourism attractions (2013-2017).

\begin{tabular}{|l|c|c|c|c|c|c|c|}
\hline \multicolumn{1}{|c|}{ Arrivals } & $\mathbf{2 0 1 3}$ & $\mathbf{2 0 1 4}$ & $\mathbf{2 0 1 5}$ & $\mathbf{2 0 1 6}$ & $\mathbf{2 0 1 7}$ & Total & Percent \\
\hline Other Africans & 65 & 52 & 71 & 159 & 399 & 746 & 27 \\
\hline North Americans & 41 & 38 & 57 & 134 & 153 & 423 & 15 \\
\hline South Americans & 42 & 47 & 38 & 163 & 182 & 472 & 17 \\
\hline Asians & 92 & 75 & 34 & 141 & 192 & 534 & 19 \\
\hline Europeans & 63 & 47 & 68 & 198 & 229 & 605 & 22 \\
\hline Total & 303 & 259 & 268 & 795 & 1155 & 2780 & 100 \\
\hline
\end{tabular}

Source: Hotel registry, 2017 
Table 5. Domestic visitors' that visited the ecotourism attractions (2013-2017).

\begin{tabular}{|l|c|c|c|c|c|c|c|}
\hline \multicolumn{1}{|c|}{ States } & $\mathbf{2 0 1 3}$ & $\mathbf{2 0 1 4}$ & $\mathbf{2 0 1 5}$ & $\mathbf{2 0 1 6}$ & $\mathbf{2 0 1 7}$ & Total & (\%) \\
\hline Anambra & 43 & 22 & 36 & 33 & 92 & 226 & 6 \\
\hline Imo & 42 & 53 & 27 & 32 & 71 & 225 & 6 \\
\hline Ebonyi & 21 & 18 & 48 & 68 & 116 & 271 & 8 \\
\hline Abia & 20 & 28 & 28 & 38 & 75 & 189 & 5 \\
\hline Niger & 28 & 35 & 42 & 48 & 72 & 225 & 6 \\
\hline Cross River & 26 & 39 & 32 & 69 & 187 & 353 & 10 \\
\hline Akwa Ibom & 13 & 43 & 36 & 40 & 75 & 207 & 6 \\
\hline Rivers & 39 & 37 & 41 & 59 & 198 & 374 & 10 \\
\hline Delta & 14 & 27 & 28 & 32 & 79 & 180 & 5 \\
\hline Edo & 27 & 15 & 19 & 22 & 188 & 271 & 8 \\
\hline Benue & 19 & 17 & 28 & 39 & 42 & 145 & 4 \\
\hline Lagos & 38 & 69 & 61 & 79 & 85 & 332 & 9 \\
\hline Kogi & 11 & 38 & 11 & 21 & 36 & 117 & 3 \\
\hline Bayelsa & 11 & 26 & 23 & 29 & 41 & 130 & 4 \\
\hline Abuja & 32 & 39 & 69 & 34 & 161 & 335 & 9 \\
\hline Total & 384 & 506 & 529 & 643 & 1518 & 3580 & 100 \\
\hline
\end{tabular}

Source: Hotel registry, 2017

Table 6. Visitors to the various types of ecotourism attractions between 2013 and 2017.

\begin{tabular}{|l|c|c|c|c|c|c|c|}
\hline Attractions & $\mathbf{2 0 1 3}$ & $\mathbf{2 0 1 4}$ & $\mathbf{2 0 1 5}$ & $\mathbf{2 0 1 6}$ & $\mathbf{2 0 1 7}$ & Total & Percent \\
\hline Lake & 199 & 211 & 293 & 382 & 538 & 1623 & 26 \\
\hline Waterfall & 301 & 298 & 294 & 567 & 779 & 2239 & 35 \\
\hline Landscape & 87 & 109 & 164 & 188 & 321 & 869 & 14 \\
\hline Caves & 60 & 90 & 30 & 161 & 735 & 1076 & 17 \\
\hline Shrine & 40 & 57 & 16 & 140 & 300 & 553 & 9 \\
\hline Total & 687 & 765 & 797 & 1438 & 2673 & 6360 & 100 \\
\hline
\end{tabular}

Source: Ecotourism attraction's registry, 2017

The study considered the rate of visits to various ecotourism attractions within the study area and formulated hypothesis for testing using information on Table 6 and 7. One way analysis of variance statistical technique was adopted to test the formulated hypothesis.

$\mathrm{H}_{\mathrm{o}}$ : There is no significant variation in the number of visitors to the various ecotourism attractions in the study area

$\mathrm{H}_{\mathrm{I}}$ : There is a significant variation in the number of visitors to the various ecotourism attractions in the study area

The test of variation on Tables 7 and 8 shows that the number of visitors to the ecotourism attractions varies significantly across the years (2013 to 2017) with the F-ratio of ( $\mathrm{F}=5.668$, $\mathrm{P}<0.05$ ). This means that there is a significant variation in the number of visitors across the years under investigation and with this, the null hypothesis is rejected and the alternate hypothesis accepted. The implication of this result is that some attractions received more visitors than the others. The study attributed this high varying number to some deterring factors such as lack of awareness of the site, lack of good road accessibility, lack of support facilities, infrastructures or amenities in some of the less visited attractions. 
Table 7. Result of One way ANOVA (Descriptive) of visits to ecotourism attractions

\begin{tabular}{|l|r|r|r|r|r|r|r|r|}
\hline & \multirow{2}{*}{$\mathbf{N}$} & Mean & Std. Deviation & \multicolumn{1}{c|}{$\begin{array}{c}\text { Std. } \\
\text { Error }\end{array}$} & \multicolumn{2}{|c|}{$\begin{array}{r}\text { 95\% Confidence Interval for } \\
\text { Mean }\end{array}$} & Minimum & Maximum \\
\hline & & & & & Lower Bound & Upper Bound & & \\
\hline 2013 & 5 & 137 & 110 & 49 & .5672 & 274 & 40.00 & 301.00 \\
2014 & 5 & 153 & 99 & 44 & 29.5965 & 276 & 57.00 & 298.00 \\
2015 & 5 & 159 & 135 & 60 & -8.6784 & 327 & 16.00 & 294.00 \\
2016 & 5 & 287 & 183 & 82 & 59.7376 & 515 & 140.00 & 567.00 \\
2017 & 5 & 534 & 223 & 100 & 256.5635 & 812 & 300.00 & 779.00 \\
Total & 25 & 254 & 210 & 42 & 167.6627 & 341 & 16.00 & 779.00 \\
\hline
\end{tabular}

Source: Author's analysis, 2017

Table 8. Result of visitors visits to various attraction types in the area.

\begin{tabular}{|l|r|r|r|r|r|}
\hline Number of Visitors & \multicolumn{1}{|c|}{ Sum of Squares } & \multicolumn{1}{|c|}{ df } & Mean Square & \multicolumn{1}{c|}{ F } & \multicolumn{1}{c|}{ Sig. } \\
\hline Between Groups & 563051.200 & 4 & 140762.800 & 5.668 & 0.003 \\
Within Groups & 496656.800 & 20 & 24832.840 & & \\
& 1059708.000 & 24 & & & \\
Total & & & & \\
\hline
\end{tabular}

Source: Author's analysis, 2017

Information on Figure 4 revealed that $54 \%$ of the visitors confirmed that they got to know about the attraction through information from interaction with friends and family members. $21 \%$ of the visitors also confirmed that they got their own information through the social media while $7 \%$ and $8 \%$ had their information about the attraction through conferences and the print media respectively. This clearly confirmed the saying that information is power and that a good turn deserves another. This is because if those who informed the visitors had not gotten satisfactory treatment when they visited the attraction, they wouldn't have said good of the attraction to attract more visitor's patronage.

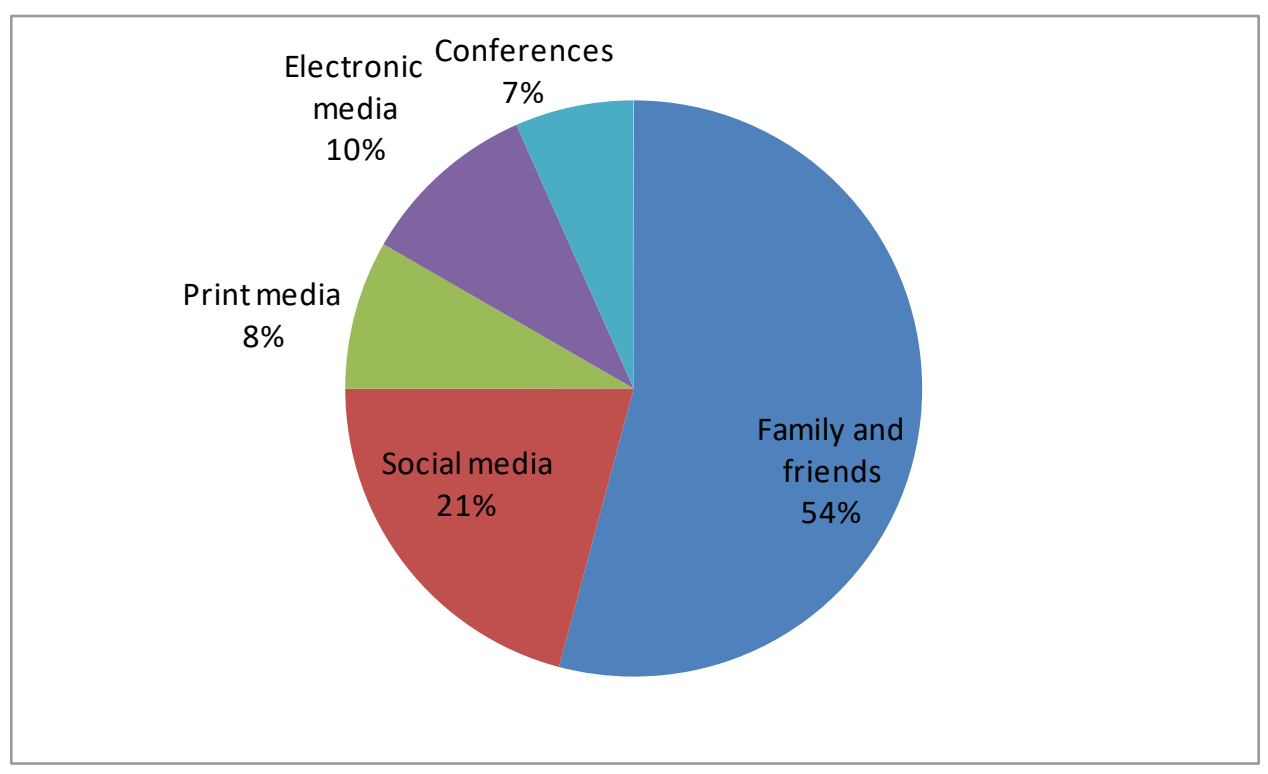

Figure 4. Medium of awareness of the ecotourism attractions.

Source: Field survey, 2017

The study also examined the challenges limiting the development of ecotourism attractions within the study area. Information on Fig. 5 revealed that lack of government and private sector 
collaboration and interest were the highest recorded challenges with $32 \%$ and $28 \%$ of the respondent's opinion respectively. This was closely followed by those who supported that lack of accessible roads with $15 \%$ and lack of trained staffs and lack of infrastructures with $10 \%$ each respectively were the most pressing challenging factors. The least recorded factor challenging the development and smooth running of ecotourism attractions was that of insecurity which recorded $5 \%$ of the respondent's opinion. This simply implies that lack of stakeholder's collaboration has really affected the development of ecotourism attractions within the study area.

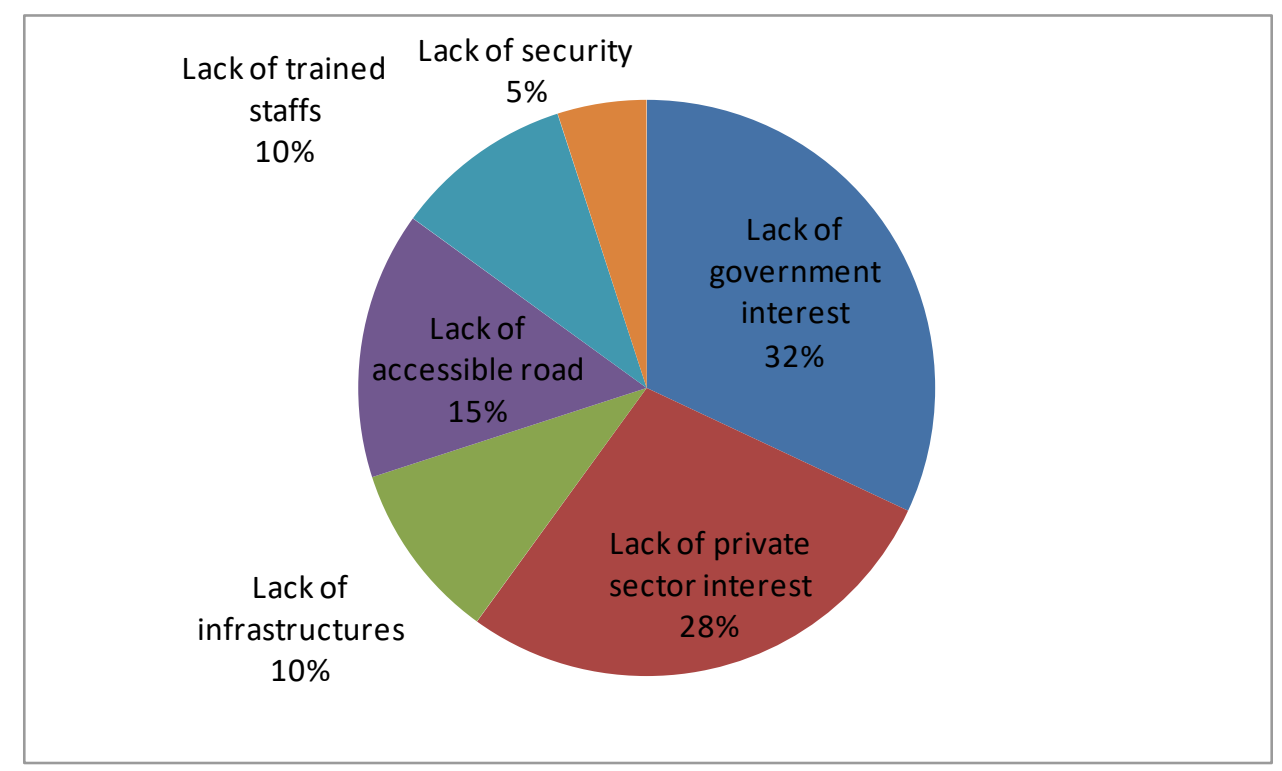

Figure 5. Challenges limiting the development of ecotourism attractions in the study area.

Source: Author's survey, 2017

\section{Conclusion and Recommendations}

The study examined the spatial distribution of eco-tourism attractions within the study area. It was discovered that there were forty one (41) operational ecotourism attractions within the study area and that the attractions were located in-between $0.1 \mathrm{~km}$ and $2.2 \mathrm{~km}$ apart from the closest and the most distanced attractions to each other respectively. This made the study to conclude that the attractions are randomly distributed within the area as the value from the nearest neighbor analysis was 0.93 . This finding is in agreement with that of $[8,15,25]$ which reported that proximity of attractions and support facilities is a major factor that ensures more visits or patronage.

Similarly, analysis of visitors' patronage of ecotourism attractions within the study area revealed that a total of six thousand, three hundred and sixty (6360) people who visited the attractions between 2013 and 2017. Among these visitors were three thousand, five hundred and eighty (3580) domestic visitors (people who visited from within the country) representing 56 percent of the entire visitors while two thousand, seven hundred and eighty (2780) international visitors (people who visited from outside the country) representing 44 percent of the entire visitors to the various ecotourism attractions respectively. This clearly emphasize that people who travel within the same country find it more easy and convenient to travel to spend time for recreation than those who travel across a country's boundary and this has made it factual that ecotourism destinations normally witness more visits from domestic visitors than their international counterparts.

Finally, the study observed that there were some major factors that affects the development and packaging of ecotourism attractions in the area. Among these factors were lack of collaboration and interest from stakeholders to invest in the development of ecotourism attractions in the area. This reflects the findings of $[16,28]$ who emphasized that ecotourism development strives more where there are significant collaboration between major stakeholders (government, private sector investors and host people). 
Based on these findings, the study suggest that Government and other stakeholders of the industry (private investors and host communities) should be carried along and committed in improving the ecotourism attractions by collaborating and working hand in hand to ensure better conditions of the facilities and amenities within and around the attraction sites. It was also recommended that more advertisement and marketing strategies be employed to create more awareness of the attractions and its facilities to the entire world.

\section{Conflict of Interest}

The authors declare that there is no conflict of interest.

\section{References}

[1] A.O. Ajake, T.E. Amalu, The relevance of tourism on the economic development of Cross River state, Nigeria, Journal of Geography and Regional Planning. 5(1) (2012) 11-25.

[2] A.O. Ajake, T.E. Amalu, Participation of Becheeve people in tourism development in Obudu Mountain resort, Cross River state, Nigeria, British Journal of Humanities and Social Sciences. 3(2) (2012) 25-39.

[3] B. O. Uwadiegwu, Basics of Recreation and Tourism Facilities, Planning, Enugu: Academic Publishing Co., 2002.

[4] C. Ryan, Researching Ecotourist Satisfaction: Issues, Concepts, Problems. Routledge: London, 2005.

[5] C. Ryan, G. Cessford, Developing a visitor satisfaction monitoring methodology: Quality gaps, crowding and some results, Current Issues in Tourism. 6(6) (2003) 457-507.

[6] E.I. Eja, A.O. Ajake, Seasonal changes on resort patronage in Cross River State, Nigeria, European Journal of Tourism, Hospitality and Recreation. 2(2) (2011) 19-30.

[7] E.E. Iwara, T.E. Amalu, Assessing the seasonal patterns of visitors arrivals as an index for hotel industry growth in Calabar, Nigeria, Journal of Tourism and Management Research. 2(3) (2017) 135-146.

[8] T.E. Amalu et al., Socio-Economic impacts of ecotourism attractions in Enugu state, Nigeria, GeoJournal. (2017) 1-13.

[9] T.E. Amalu et al., Assessment of tourists' patronage of Obudu Mountain Resort, Cross River state, Nigeria, Journal of Hospitality and Management Tourism. 8(4) (2017) 32-41.

[10] T.E. Amalu, A.O. Ajake, Influence of Calabar carnival on the economy of residents of Calabar metropolis, Cross River state, Nigeria, Global Journal. 1(1) (2014) 67-81.

[11] I. A. Enang, A.O. Ajake, T.E. Amalu, Volumetric analysis of tourist arrivals in ecotourism sites of Cross River state, Nigeria, Journal of Tourism and Management Research. 1(1) (2016) 135154.

[12] A.O. Ajake et al., Assessment of cultural and museum landscapes for tourism development: The Calabar museum scenario, Cross River State, Nigeria, Journal of Tourism and Management Research. 1(1) (2016) 119-134.

[13] T.E. Amalu et al., Assessment of the influence of Education on tourism development in Enugu state, Nigeria, American Journal of Tourism Research. 1(1) (2012) 33-42.

[14] T.E. Amalu, A.O. Ajake, P.O. Obi, Impact of royalties from forest resources on community development in Boki Local Government in Cross River state, Nigeria, GeoJournal. 80(1) (2015) $122-135$. 
[15] T.E. Amalu, P.A. Ojugbo, O.O Otop, Assessment of impact of Recreational resorts on socioeconomic growth of Calabar, Cross River State, Nigeria, Sustainable Geoscience and Geotourism. 1(1) (2018) 11-24

[16] I.A. Ezeh, Selected tourists' attractions in Enugu State: Ezeagu tourist complex, Awhum waterfall and Opi lake system as case studies. Unpublished M.A Thesis, Department of Archaeology and Tourism, University of Nigeria Nsukka, 2006.

[17] X. Jin, Exhibition brand preference in mainland China: The role of relationship quality and destination attractiveness. Hong Kong institutional repositories, Thesis, XVI (308). (2011).

[18] M. Kozak, M. Rimmington, Tourist satisfaction with Mallorca, Spain, as an off-season holiday destination. Journal of Travel Research. 38 (3), (2000) 260-269.

[19] T.E. Amalu, A.O. Ajake, Developing natural lakes for socio-economic development: The case of Nike Lake, Enugu State Nigeria, GeoJournal. 78(4) (2018).

[20] T. Takon, T.E. Amalu, Assessment of natural resource conservation in Boki Local Government area, Cross River state, Nigeria, Environmental Science: An Indian Journal. 8(4) (2013) 123-131.

[21] K. Leena et al., Indicators of the criteria for good participation in Ecotourism planning at local level: A Nordic case study. Journal of Sustainable Tourism. 10(4) (2013) 451-466.

[22] N. Leiper, Tourism Management. 3rd ed. French Forest NSW: Pearson Education Australia, 2000.

[23] J. Marzuki, Taxing Cruise Tourism: Alaska's Head Tax on Cruise Ship Passengers, Tourism Economics. 14 (3) (2011) 599-614.

[24] T.E. Amalu et al., Socio-economic implication of tourists' appraisal of the Obudu Mountain resort, Cross River State, Nigeria, Journal of Environmental Science, Toxicology and Food Technology. 1(3) (2012) 37-44.

[25] T.E. Amalu, A.O. Ajake, The impact of hotel industry development in Enugu City, Nigeria, Journal of Tourism and Heritage Studies. 4(1\&2) (2015) 106-120.

[26] M. H. Mustafa, S. N. Abu Tayeh, The impact of Tourism development on the Archaeological site of Petra and local communities in surrounding villages, Asian Journal Social Science. 7 (8) (2011) 88-96.

[27] R.N. Okech, Pro-Poor vs. sustainable tourism in local communities: issues of empowerment and participation, in: K.R. Redy et al. (Eds.), Proceedings "Natural Hazards \& Disaster - Essays on Impacts and Management”, Bhattarams Publishers India, 2009, pp. 170-187.

[28] E.E. Okonkwo, C.J. Odum, Community based tourism development in selected villages in Enugu State, Nigeria. Journal of Economic Literature. 38(3) (2012) 614-631.

[29] R. Oliver, Satisfaction. A behavioural perspective on the consumer, New York: McGraw-Hill, 2007.

[30] D.M. Roxana, Considerations about ecotourism and nature-based tourism realities and perspectives. International Journal of Academic Research in Economics and Management Sciences. 1(5) (2012) 215-221.

[31] T. Takon, T.E. Amalu, D. Okpara, Assessment of local people's attitude towards natural resource conservation in Boki Local government area, Cross River state, Nigeria, Research Journal in Organizational Psychology and Education Studies. 2(2) (2013) 60-66.

[32] T.E. Amalu, Community people's participation in tourism development in Obudu Mountain resort Cross river State, Nigeria, Lambert Publishers, Germany, 2012. 
[33] K. Kulkajonplun, V. Angkasith, D. Rithmance, The development of a sustainable resort and indicators, presented at the $13^{\text {th }}$ Global Conference on Sustainable Manufacturing-decoupling growth from resource use, Procedia CIRP-40, 2016, pp. 191-196.

[34] M. Stock et al., Resort Development and Touristic Capital of Place: The Circulation of Wealth, 2014.

[35] E.J. Aniah, E.I. Eja, J.E. Otu, Resort potentials as a strategy for sustainable tourism development in Plateau State, Nigeria, Journal of Sustainable Development. 2(2) (2009) 73-79.

[36] T.E. Amalu, A.O. Ajake, An assessment of the employment structure in the tourism industry of Obudu Mountain resort, Cross River state, Nigeria, Geo-Journal of Tourism and Geosites. 9(1) (2012) 35-56. 